\title{
TURKISH JOURNAL OF
}

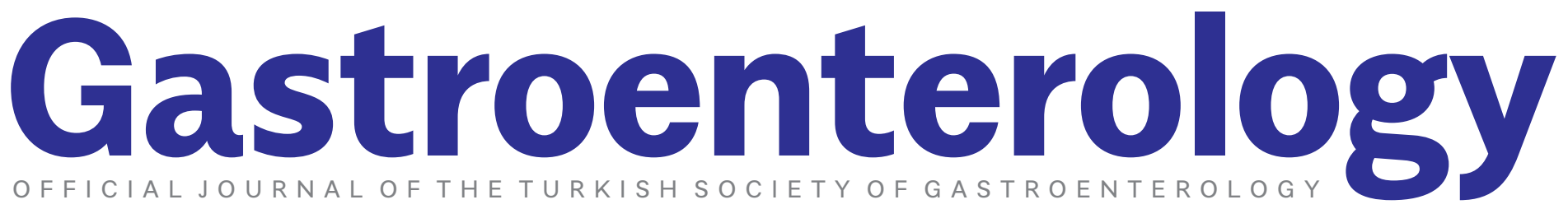

\section{Growing burden of non-alcoholic fatty liver disease in Turkey}

See page 892

877 Changing patterns of upper gastrointestinal bleeding 883 Metabolic acidosis in critically ill cirrhotic patients $\mathbf{8 9 9}$ Impaired thiol/disulfide homeostasis in acute pancreatitis 932 Cytomegalovirus colitis mimicking sigmoid tumor

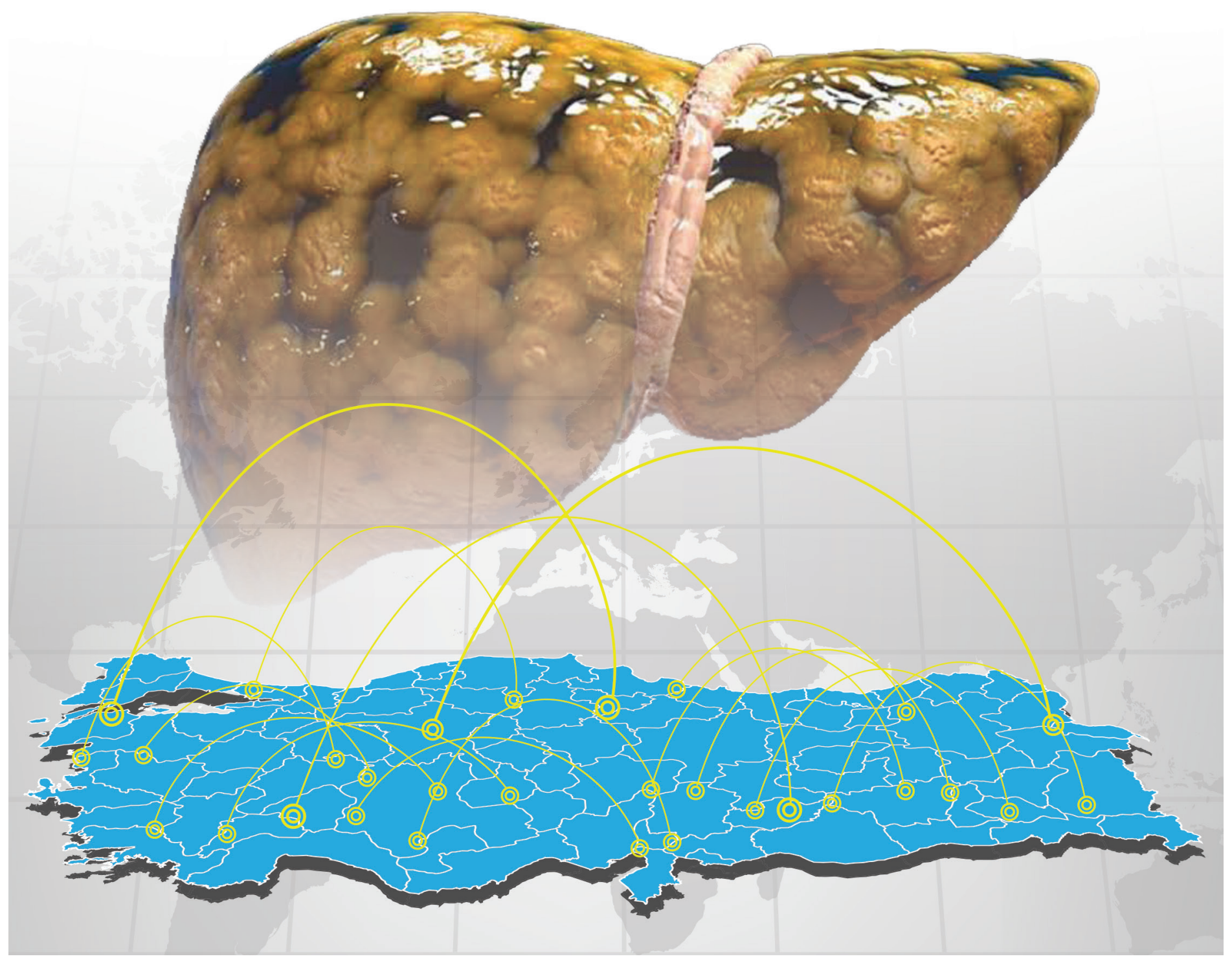




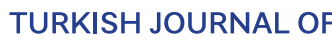 Gastroenterology}

\section{Editor in Chief}

Osman Cavit Özdoğan (1)

Department of Gastroenterology, Marmara University School of Medicine, Istanbul, Turkey

\section{Section Editors}

Ayhan Hilmi Çekin (D)

Department of Gastroenterology, Health Sciences University Antalya Training and Research Hospital, Antalya, Turkey

Ramazan Idilman (D)

Department of Gastroenterology, Ankara University School of Medicine, Ankara, Turkey

Tarkan Karakan iD

Department of Gastroenterology, Gazi University School of Medicine, Ankara, Turkey

ilter Özer (iD

Department of General Surgery, Eskişehir Osmangazi University School of Medicine, Eskişehir, Turkey

Yeşim Öztürk iD

Department of Pediatric Gastroenterology, Dokuz Eylül University School of Medicine, İzmir, Turkey

Murat Saruç iD

Department of Internal Medicine, Division of Gastroenterology, Acıbadem University School of Medicine, Istanbul, Turkey

Berrak Yeğen (D)

Department of Physiology, Marmara University School of Medicine, istanbul, Turkey

\section{Associate Editors}

Mesut Akarsu iD

Department of Gastroenterology, Dokuz Eylül University School of Medicine, Izmir, Turkey

Filiz Akyüz (D)

Department of Gastroenterology, İstanbul

University School of Medicine, İstanbul, Turkey

Canan Alkım (D)

Clinic of Gastroenterology, Şişli Etfal Training and

Research Hospital, İstanbul, Turkey

Nural Bekiroğlu (D)

Department of Biostatistics, Marmara University

School of Medicine, Istanbul, Turkey

\section{Ayhan Bozkurt iD}

Department of Physiology, Ondokuz Mayıs University School of Medicine, Samsun, Turkey

Mehmet Bülbül (iD

Department of Physiology, Akdeniz University

School of Medicine, Antalya, Turkey

\section{Ülkü Dağlı (D)}

Department of Gastroenterology, Başkent University

School of Medicine, Ankara, İstanbul, Turkey

\section{International Associate Editor}

Ali Canbay

Department of Gastroenterology, Hepatology, and Infectious Diseases, Magdeburg University Hospital, Magdeburg, Germany

\section{/AVES}

Publisher

Ibrahim KARA

Publication Director Ali ŞAHIN

Editorial Development Gizem KAYAN

Finance and Administration Zeynep YAKIŞIRER ÜREN

Selçuk Dişibeyaz (i)

Department of Gastroenterology, Eskişehir

Osmangazi University School of Medicine,

Eskişehir Turkey

Deniz Güney Duman (D)

Department of Gastroenterology, Marmara

University School of Medicine, Istanbul, Turkey

Fulya Günşar (iD)

Department of Gastroenterology, Ege University School of Medicine, Izmir, Turkey

Aydın Şeref Köksal (iD

Department of Gastroenterology, Sakarya University

School of Medicine, Sakarya, Turkey

Dilek Oğuz

Department of Gastroenterology, Kirıkkale

University School of Medicine, Kırıkkale, Turkey

Volkan Öter

Department of General Surgery, Sakarya University School of Medicine, Sakarya, Turkey

Sedef Özdal Kuran (D)

Department of Gastroenterology, Çukurova

University School of Medicine, Balçalı Hospital,

Adana, Turkey

\section{Ahmet Gürakar (iD}

Department of Gastroenterology and Hepatology, Johns Hopkins University School of Medicine,

Baltimore, USA

\section{Deputy Publication Director \\ Gökhan ÇIMEN}

Publication Coordinators

Betül ÇiMEN

Özlem CAKMAK

Okan AYDOĞAN

Irem DELICAYY

Arzu YILDIRIM
Müjde Soytürk (D)

Department of Gastroenterology, Dokuz Eylül University School of Medicine, Izmir, Turkey

Fatih Tekin (D)

Department of Gastroenterology, Ege University School of Medicine, Izmir, Turkey

ilker Turan (iD

Department of Gastroenterology, Ege University School of Medicine, İmir, Turkey

Gökhan Tümgör (D)

Department of Pediatric, Division of Pediatric Gastroenterology, Çukurova University School of Medicine, Adana, Turkey

Ayşen Uncuoğlu iD

Department of Pediatric, Division of Pediatric Gastroenterology, Kocaeli University School of Medicine, Kocaeli, Turkey

Yücel Üstündağ (iD

Department of Gastroenterology, Bülent Ecevit University School of Medicine, Zonguldak, Turkey

Müjdat Zeybel (iD

Department of Gastroenterology, Koç University Hospital, Istanbul, Turkey

\section{Production Coordinator}

Cem Aygün (i)

Department of Gastroenterology, Acıbadem

Hospital, İstanbul, Turkey

\section{Project Coordinators Doğan ORUÇ Sinem KOZ}

Graphics Department Ünal ÖZER

Deniz DURAN

Beyzanur KARABULUT
Address: Büyükdere Cad. No: 105/9 34394 Mecidiyeköy, Şişli, Istanbul-Turkey

Phone: +90212 2171700

Fax: +902122172292

E-mail:info@avesyayincilik.com 


\section{runass}

\section{Aims and Scope}

Turkish Journal of Gastroenterology (Turk J Gastroenterol) is the double-blind peer-reviewed, open access, international publication organ of the Turkish Society of Gastroenterology. The journal is published monthly and its publication language is English.

Turkish Journal of Gastroenterology aims to publish international at the highest clinical and scientific level on original issues of gastroenterology and hepatology. The journal publishes original papers, review articles, and letters to the editor on clinical and experimental gastroenterology and hepatology.

The editorial and publication processes of the journal are shaped in accordance with the guidelines of the International Committee of Medical Journal Editors (ICMJE), World Association of Medical Editors (WAME), Council of Science Editors (CSE), Committee on Publication Ethics (COPE), European Association of Science Editors (EASE), and National Information Standards Organization (NISO). The journal is in conformity with the Principles of Transparency and Best Practice in Scholarly Publishing (doaj.org/bestpractice).

The Turkish Journal of Gastroenterology is indexed in Science Citation Index Expanded, PubMed/MEDLINE, Scopus, and TUBITAK ULAKBIM TR Index.

Processing and publication are free of charge with the journal. No fees are requested from the authors at any point throughout the evaluation and publication process. All manuscripts must be submitted via the online submission system, which is available at turkjgastroenterol.org. The journal guidelines, technical information, and the required forms are available on the journal's web page.
All expenses of the journal are covered by the Turkish Society of Gastroenterology. Potential advertisers should contact the Editorial Office. Advertisement images are published only upon the Editor-in-Chief's approval.

Statements or opinions expressed in the manuscripts published in the journal reflect the views of the author(s) and not the opinions of the Turkish Society of Gastroenterology, editors, editorial board, and/or publisher; the editors, editorial board, and publisher disclaim any responsibility or liability for such materials.

All published content is available online, free of charge at turkjgastroenterol.org.

Turkish Society of Gastroenterology holds the international copyright of all the content published in the journal.

\section{Editor in Chief: Prof. Osman Cavit Özdoğan}

Address: Mustafa Kemal Mahallesi, 2126 Sokak, Kolbay İş Merkezi, C blok, No.: 6-9, Çankaya, Ankara, TURKEY

Phone: +903122841511

Fax: +903122848075

E-mail: dernek@tgd.org.tr

Publisher: AVES

Address: Büyükdere Cad., 105/9 34394 Mecidiyeköy, Şişli, İstanbul, TURKEY

Phone: +90212 2171700

Fax: +902122172292

E-mail:info@avesyayincilik.com

Web page: avesyayincilik.com

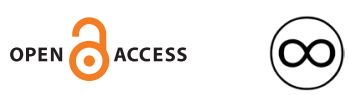




\section{Instructions to Authors}

Turkish Journal of Gastroenterology (Turk J Gastroenterol) is the double-blind peer-reviewed, open access, international publication organ of the Turkish Society of Gastroenterology. The journal is published monthly and its publication language is English.

Turkish Journal of Gastroenterology aims to publish international at the highest clinical and scientific level on original issues of gastroenterology and hepatology. The journal publishes original papers, review articles and letters to the editor on clinical and experimental gastroenterology and hepatology.

The editorial and publication processes of the journal are shaped in accordance with the guidelines of the International Council of Medical Journal Editors (ICMJE), the World Association of Medical Editors (WAME), the Council of Science Editors (CSE), the Committee on Publication Ethics (COPE), the European Association of Science Editors (EASE), and National Information Standards Organization (NISO). The journal conforms to the Principles of Transparency and Best Practice in Scholarly Publishing (doaj.org/bestpractice).

Originality, high scientific quality, and citation potential are the most important criteria for a manuscript to be accepted for publication. Manuscripts submitted for evaluation should not have been previously presented or already published in an electronic or printed medium. The journal should be informed of manuscripts that have been submitted to another journal for evaluation and rejected for publication. The submission of previous reviewer reports will expedite the evaluation process. Manuscripts that have been presented in a meeting should be submitted with detailed information on the organization, including the name, date, and location of the organization.

Manuscripts submitted to the Turkish Journal of Gastroenterology will go through a double-blind peer-review process. Each submission will be reviewed by at least two external, independent peer reviewers who are experts in their fields in order to ensure an unbiased evaluation process. The editorial board will invite an external and independent editor to manage the evaluation processes of manuscripts submitted by editors or by the editorial board members of the journal. The Editor in Chief is the final authority in the decision-making process for all submissions.

An approval of research protocols by the Ethics Committee in accordance with international agreements (World Medical Association Declaration of Helsinki "Ethical Principles for Medical Research Involving Human Subjects," amended in October 2013, www.wma.net) is required for experimental, clinical, and drug studies. If required, ethics committee reports or an equivalent official document will be requested from the authors. For manuscripts concerning experimental research on humans, a statement should be included that shows that written informed consent of patients and volunteers was obtained following a detailed explanation of the procedures that they may undergo. For studies carried out on animals, the measures taken to prevent pain and suffering of the animals should be stated clearly. Information on patient consent, the name of the ethics committee, and the ethics committee approval number should also be stated in the Materials and Methods section of the manuscript. It is the authors' responsibility to carefully protect the patients' anonymity. For photographs that may reveal the identity of the patients, releases signed by the patient or their legal representative should be enclosed.

All submissions are screened by a similarity detection software (iThenticate by CrossCheck).

In the event of alleged or suspected research misconduct, e.g., plagiarism, citation manipulation, and data falsification/fabrication, the Editorial Board will follow and act in accordance with COPE guidelines.

Each individual listed as an author should fulfill the authorship criteria recommended by the International Committee of Medical Journal Editors (ICMJE-www.icmje.org). The ICMJE recommends that authorship be based on the following 4 criteria:

1. Substantial contributions to the conception or design of the work; or the acquisition, analysis, or interpretation of data for the work; AND

2. Drafting the work or revising it critically for important intellectual content; AND

3. Final approval of the version to be published; AND

4. Agreement to be accountable for all aspects of the work in ensuring that questions related to the accuracy or integrity of any part of the work are appropriately investigated and resolved.

In addition to being accountable for the parts of the work he/she has done, an author should be able to identify which co-authors are responsible for specific other parts of the work. In addition, authors should have confidence in the integrity of the contributions of their co-authors.

All those designated as authors should meet all four criteria for authorship, and all who meet the four criteria should be identified as 


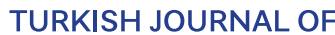 Gastroenterology}

authors. Those who do not meet all four criteria should be acknowledged in the title page of the manuscript.

Turkish Journal of Gastroenterology requires corresponding authors to submit a signed and scanned version of the authorship contribution form (available for download through turkjgastroenterol.org) during the initial submission process in order to act appropriately on authorship rights and to prevent ghost or honorary authorship. If the editorial board suspects a case of "gift authorship," the submission will be rejected without further review. As part of the submission of the manuscript, the corresponding author should also send a short statement declaring that he/she accepts to undertake all the responsibility for authorship during the submission and review stages of the manuscript.

Turkish Journal of Gastroenterology requires and encourages the authors and the individuals involved in the evaluation process of submitted manuscripts to disclose any existing or potential conflicts of interests, including financial, consultant, and institutional, that might lead to potential bias or a conflict of interest. Any financial grants or other support received for a submitted study from individuals or institutions should be disclosed to the Editorial Board. To disclose a potential conflict of interest, the ICMJE Potential Conflict of Interest Disclosure Form should be filled in and submitted by all contributing authors. Cases of a potential conflict of interest of the editors, authors, or reviewers are resolved by the journal's Editorial Board within the scope of COPE and ICMJE guidelines.

The Editorial Board of the journal handles all appeal and complaint cases within the scope of COPE guidelines. In such cases, authors should get in direct contact with the editorial office regarding their appeals and complaints. When needed, an ombudsperson may be assigned to resolve cases that cannot be resolved internally. The Editor in Chief is the final authority in the decision-making process for all appeals and complaints.

When submitting a manuscript to Turkish Journal of Gastroenterology, authors accept to assign the copyright of their manuscript to the Turkish Society of Gastroenterology. If rejected for publication, the copyright of the manuscript will be assigned back to the authors. Turkish Journal of Gastroenterology requires each submission to be accompanied by a Copyright Transfer Form (available for download at turkjgastroenterol.org). When using previously published content, including figures, tables, or any other material in both print and electronic formats, authors must obtain permission from the copyright holder. Legal, financial and criminal liabilities in this regard belong to the author(s).
Statements or opinions expressed in the manuscripts published in Turkish Journal of Gastroenterology reflect the views of the author(s) and not the opinions of the editors, the editorial board, or the publisher; the editors, the editorial board, and the publisher disclaim any responsibility or liability for such materials. The final responsibility in regard to the published content rests with the authors.

\section{Manuscript Preparation}

The manuscripts should be prepared in accordance with ICMJERecommendations for the Conduct, Reporting, Editing, and Publication of Scholarly Work in Medical Journals (updated in December 2018 - http://www.icmje.org/icmje-recommendations.pdf). Authors are required to prepare manuscripts in accordance with the $\mathrm{CON}$ SORT guidelines for randomized research studies, STROBE guidelines for observational original research studies, STARD guidelines for studies on diagnostic accuracy, PRISMA guidelines for systematic reviews and meta-analysis, ARRIVE guidelines for experimental animal studies, and TREND guidelines for non-randomized public behavior.

Manuscripts can only be submitted through the journal's online manuscript submission and evaluation system, available at turkjgastroenterol.org. Manuscripts submitted via any other medium will not be evaluated.

Manuscripts submitted to the journal will first go through a technical evaluation process where the editorial office staff will ensure that the manuscript has been prepared and submitted in accordance with the journal's guidelines. Submissions that do not conform to the journal's guidelines will be returned to the submitting author with technical correction requests.

Authors are required to submit the following:

- Copyright Transfer Form,

- Author Contributions Form, and

- ICMJE Potential Conflict of Interest Disclosure Form (should be filled in by all contributing authors) during the initial submission. These forms are available for download at turkjgastroenterol.org.

\section{Preparation of the Manuscript}

Title page: A separate title page should be submitted with all submissions and this page should include:

- The full title of the manuscript as well as a short title (running head) of no more than 50 characters,

- Name(s), affiliations, and highest academic degree(s) of the author(s), 


\section{TURKISH JOURNAL OF}

- Grant information and detailed information on the other sources of support,

- Name, address, telephone (including the mobile phone number) and fax numbers, and email address of the corresponding author,

- Acknowledgment of the individuals who contributed to the preparation of the manuscript but who do not fulfill the authorship criteria.

\section{Abstract}

An English abstract should be submitted with all submissions except for Letters to the Editor. Submitting a Turkish abstract is not compulsory for international authors. The abstract of Original Articles should be structured with subheadings (Background/Aims, Materials and Methods, Results, and Conclusion). Please check Table 1 below for word count specifications.

Table 1. Limitations for each manuscript type

\begin{tabular}{|c|c|c|c|c|c|}
\hline $\begin{array}{l}\text { Type of } \\
\text { manuscript }\end{array}$ & $\begin{array}{l}\text { Word } \\
\text { limit }\end{array}$ & $\begin{array}{l}\text { Abstract } \\
\text { word limit }\end{array}$ & $\begin{array}{c}\text { Reference } \\
\text { limit }\end{array}$ & $\begin{array}{l}\text { Table } \\
\text { limit }\end{array}$ & $\begin{array}{c}\text { Figure } \\
\text { limit }\end{array}$ \\
\hline $\begin{array}{l}\text { Original } \\
\text { Article }\end{array}$ & 3500 & $\begin{array}{c}250 \\
\text { (Structured) }\end{array}$ & 30 & 6 & $\begin{array}{c}7 \text { or total of } \\
15 \text { images }\end{array}$ \\
\hline $\begin{array}{l}\text { Review } \\
\text { Article }\end{array}$ & 5000 & 250 & 50 & 6 & $\begin{array}{c}10 \text { or total of } \\
20 \text { images }\end{array}$ \\
\hline $\begin{array}{l}\text { Letter to } \\
\text { the Editor }\end{array}$ & 1000 & $\begin{array}{c}\text { No } \\
\text { abstract }\end{array}$ & 5 & $\begin{array}{c}\text { No } \\
\text { tables }\end{array}$ & $\begin{array}{c}2 \text { or total of } \\
4 \text { images }\end{array}$ \\
\hline $\begin{array}{l}\text { Diagnostic } \\
\text { Challenge }\end{array}$ & 1200 & $\begin{array}{c}\text { No } \\
\text { abstract }\end{array}$ & 5 & $\begin{array}{c}\text { No } \\
\text { tables }\end{array}$ & $\begin{array}{c}7 \text { or total of } \\
15 \text { images }\end{array}$ \\
\hline
\end{tabular}

Keywords: Each submission must be accompanied by a minimum of three to a maximum of six keywords for subject indexing at the end of the abstract. The keywords should be listed in full without abbreviations. The keywords should be selected from the National Library of Medicine, Medical Subject Headings database (https://www.nlm. nih.gov/mesh/MBrowser.html).

\section{Manuscript Types}

Original Articles: This is the most important type of article since it provides new information based on original research. The main text of original articles should be structured with Introduction, Materials and Methods, Results, and Discussion subheadings. Please check Table 1 for the limitations for Original Articles.

Statistical analysis to support conclusions is usually necessary. Statistical analyses must be conducted in accordance with internation- al statistical reporting standards (Altman DG, Gore SM, Gardner MJ, Pocock SJ. Statistical guidelines for contributors to medical journals. Br Med J 1983: 7; 1489-93). Information on statistical analyses should be provided with a separate subheading under the Materials and Methods section and the statistical software that was used during the process must be specified.

Units should be prepared in accordance with the International System of Units (SI).

\section{Editorial Comments}

Editorial comments aim to provide a brief critical commentary by reviewers with expertise or with high reputation in the topic of the research article published in the journal. Authors are selected and invited by the journal to provide such comments. Abstract, Keywords, and Tables, Figures, Images, and other media are not included.

\section{Review Articles}

Reviews prepared by authors who have extensive knowledge on a particular field and whose scientific background has been translated into a high volume of publications with a high citation potential are welcomed. These authors may even be invited by the journal. Reviews should describe, discuss, and evaluate the current level of knowledge of a topic in clinical practice and should guide future studies. The main text should contain Introduction, Clinical and Research Consequences, and Conclusion sections. Please check Table 1 for the limitations for Review Articles.

\section{Letters to the Editor}

This type of manuscript discusses important parts, overlooked aspects, or lacking parts of a previously published article. Articles on subjects within the scope of the journal that might attract the readers' attention, particularly educative and rare cases, may also be submitted in the form of a "Letter to the Editor." Readers can also present their comments on the published manuscripts in the form of a "Letter to the Editor." Abstract, Keywords, and Tables, Figures, Images, and other media should not be included. The text should be unstructured. The manuscript that is being commented on must be properly cited within this manuscript.

\section{Diagnostic Challenge}

Turkish Journal of Gastroenterology encourages authors to submit their striking clinical images that may challenge and inform readers and contribute to their education. This type of submissions should present the image as an "unknown" and should encourage the readers to interpret and diagnose the image. The answer will be 


\section{runsast}

presented on a separate page of the issue so the main text or the title should not reveal the answer. The case should be described in the first part; the answer should discuss the image findings and the diagnosis. The article should not be longer than 1200 words.

\section{Quick look to guidelines}

These manuscripts are summaries of published guidelines. Abstract, Keywords, and Tables, Figures, Images, and other media should not be included. The text should be unstructured. The guideline that is being summarized must be properly cited within the manuscript.

\section{Tables}

Tables should be included in the main document, presented after the reference list, and they should be numbered consecutively in the order they are referred to within the main text. A descriptive title must be placed above the tables. Abbreviations used in the tables should be defined below the tables by footnotes (even if they are defined within the main text). Tables should be created using the "insert table" command of the word processing software and they should be arranged clearly to provide easy reading. Data presented in the tables should not be a repetition of the data presented within the main text but should be supporting the main text.

\section{Figures and Figure Legends}

Figures, graphics, and photographs should be submitted as separate files (in TIFF or JPEG format) through the submission system. The files should not be embedded in a Word document or the main document. When there are figure subunits, the subunits should not be merged to form a single image. Each subunit should be submitted separately through the submission system. Images should not be labeled $(a, b, c$, etc.) to indicate figure subunits. Thick and thin arrows, arrowheads, stars, asterisks, and similar marks can be used on the images to support figure legends. Like the rest of the submission, the figures too should be blind. Any information within the images that may indicate an individual or institution should be blinded. The minimum resolution of each submitted figure should be 300 DPI. To prevent delays in the evaluation process, all submitted figures should be clear in resolution and large in size (minimum dimensions: $100 \times 100 \mathrm{~mm}$ ). Figure legends should be listed at the end of the main document.

All acronyms and abbreviations used in the manuscript should be defined at first use, both in the abstract and in the main text. The abbreviation should be provided in parentheses following the definition.
When a drug, product, hardware, or software program is mentioned within the main text, product information, including the name of the product, the producer of the product, and city and the country of the company (including the state if in USA), should be provided in parentheses in the following format: "Discovery St PET/CT scanner (General Electric, Milwaukee, WI, USA)"

All references, tables, and figures should be referred to within the main text, and they should be numbered consecutively in the order they are referred to within the main text. Limitations, drawbacks, and the shortcomings of original articles should be mentioned in the Discussion section before the conclusion paragraph.

\section{References}

While citing publications, preference should be given to the latest, most up-to-date publications. If an ahead-of-print publication is cited, the DOI number should be provided. Authors are responsible for the accuracy of references. Journal titles should be abbreviated in accordance with the journal abbreviations in Index Medicus/ MEDLINE/PubMed. When there are six or fewer authors, all authors should be listed. If there are seven or more authors, the first three authors should be listed followed by "et al." In the main text of the manuscript, references should be cited using Arabic numbers in parentheses. The reference styles for different types of publications are presented in the following examples.

\section{Journal Article}

Rankovic A, Rancic N, Jovanovic M, et al. Impact of imaging diagnostics on the budget - Are we spending too much? Vojnosanit Pregl 2013; 70: 709-11.

\section{Book Section}

Suh KN, Keystone JS. Malaria and babesiosis. Gorbach SL, Barlett JG, Blacklow NR, editors. Infectious Diseases. Philadelphia: Lippincott Williams; 2004.p.2290-308.

\section{Books with a Single Author}

Sweetman SC. Martindale the Complete Drug Reference. 34th ed. London: Pharmaceutical Press; 2005

\section{Editor(s) as Author}

Huizing EH, de Groot JAM, editors. Functional reconstructive nasal surgery. Stuttgart-New York: Thieme; 2003.

\section{Conference Proceedings}

Bengisson S. Sothemin BG. Enforcement of data protection, privacy and security in medical informatics. In: Lun KC, Degoulet $P$, Piemme TE, Rienhoff O, editors. MEDINFO 92. Proceedings of the 7th World 


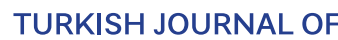

Gastroenterology

Congress on Medical Informatics; 1992 Sept 6-10; Geneva, Switzerland. Amsterdam: North-Holland; 1992. pp.1561-5.

\section{Scientific or Technical Report}

Cusick M, Chew EY, Hoogwerf B, Agrón E, Wu L, Lindley A, et al. Early Treatment Diabetic Retinopathy Study Research Group. Risk factors for renal replacement therapy in the Early Treatment Diabetic Retinopathy Study (ETDRS), Early Treatment Diabetic Retinopathy Study Kidney Int: 2004. Report No: 26.

\section{Thesis}

McCracken Jenna Mae. Mechanisms and consequences of neutrophil apoptosis inhibition by Francisella tularensis. University of lowa, PhD (Doctor of Philosophy) thesis, 2017.

\section{Manuscripts Accepted for Publication, Not Published Yet}

Slots J. The microflora of black stain on human primary teeth. Scand J Dent Res. 1974.

\section{Epub Ahead of Print Articles}

Cai L, Yeh BM, Westphalen AC, Roberts JP, Wang ZJ. Adult living donor liver imaging. Diagn Interv Radiol. 2016 Feb 24. doi: 10.5152/ dir.2016.15323. [Epub ahead of print].

\section{Manuscripts Published in Electronic Format}

Morse SS. Factors in the emergence of infectious diseases. Emerg Infect Dis (serial online) 1995 Jan-Mar (cited 1996 June 5): 1(1): (24 screens). Available from: URL: http:/ www.cdc.gov/ncidodIEID/cid.htm.

\section{Revisions}

When submitting a revised version of a paper, the author must submit a detailed "Response to the reviewers" that states point by point how each issue raised by the reviewers has been covered and where it can be found (each reviewer's comment, followed by the author's reply and line numbers where the changes have been made) as well as an annotated copy of the main document. Revised manuscripts must be submitted within 30 days from the date of the decision letter. If the revised version of the manuscript is not submitted within the allocated time, the revision option may be canceled. If the submitting author(s) believe that additional time is required, they should request this extension before the initial 30day period is over.

Accepted manuscripts are copy-edited for grammar, punctuation, and format. Once the publication process of a manuscript is completed, it is published online on the journal's webpage as an aheadof-print publication before it is included in its scheduled issue. A PDF proof of the accepted manuscript is sent to the corresponding author and their publication approval is requested within 2 days of their receipt of the proof.

Editor in Chief: Prof. Osman Cavit Özdoğan

Address: Mustafa Kemal Mahallesi, 2126 Sokak, Kolbay İş Merkezi, C blok, No.: 6-9, Çankaya, Ankara, TURKEY

Phone: +903122841511

Fax: +90312 2848075

E-mail: dernek@tgd.org.tr

Publisher: AVES

Address: Büyükdere Cad., 105/9 34394

Mecidiyeköy, Şişli, İstanbul, TURKEY

Phone: +90212 2171700

Fax: +902122172292

E-mail:info@avesyayincilik.com

Web page: avesyayincilik.com 


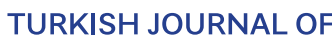

\section{Table of Contents}

\section{Covering the Cover}

863 Cem Şimşek

\section{Review}

865 Non-alcoholic fatty liver disease: A growing public health problem in Turkey

Eda Kaya, Yusuf Yılmaz

\section{Original Articles}

\section{Gastrointestinal Tract}

872 Investigation of JAM-A (rs790056) and LFA-1 (rs8058823) gene variants in Turkish colorectal cancer patients

Burcu Çaykara, Hani Alsaadoni, Halime Hanım Pençe, Sadrettin Pençe, Hülya Yılmaz Aydoğan, Didem Taştekin

$\mathbf{8 7 7}$ Changing patterns of upper gastrointestinal bleeding over 23 years in Turkey

Nilay Danış, Fatih Tekin, Ulus Salih Akarca, Nalan Gülsen Ünal, Elvan Işık Erdoğan Kıvanç Akat, Ümit Demirkoparan, Zeki Karasu, Ilker Turan, Nevin Oruç, Ahmet Aydın, Galip Ersöz, Rukiye Vardar, Ömer Özütemiz, Fulya Günşar

Liver

883 Metabolic acidosis in critically ill patients with cirrhosis: Epidemiology and short-term mortality risk factors Feng Gao, Miao-Tong Lin, Xing-Yi Yang, Meng-Xing Cai, Hao-Nan, Wei Xie, Zhi-Ming Huang

892 Growing burden of nonalcoholic fatty liver disease in Turkey: A single-center experience

Yusuf Yılmaz, Haluk Tarık Kanı, Coşkun Özer Demirtaş, Eda Kaya, Aybüke Fatma Sapmaz, Lubna Qutranji, Tasnim Alkayyali, Kerim Deniz Batun, Mahmut Batman, Berk Toy, Aslı Çiftaslan

\section{PANCREATOBILIARY}

899 Impaired thiol/disulfide homeostasis in patients with mild acute pancreatitis

Ahmet Uyanıkoğlu, Tevfik Sabuncu, Rukiye Yıldız, Çiğdem Cindoğlu, Adnan Kirmit, Özcan Erel

\section{GASTROINTESTINAL ENDOSCOPY}

903 Should pancreas cyst fluids be divided into two for cytological diagnosis and biochemical tests?

Davut Şahin, Bahattin Çiçek, ilkser Akpolat, Gürhan Şişman, Nilgün Tekkeşin

\section{GASTROINTESTINAL SURGERY}

910 Palliative resection of primary site in advanced gastroenteropancreatic neuroendocrine tumors improves survivals

Derya Kıvrak Salim, Selami Bayram, İsmail Gömceli, Ayhan Hilmi Çekin, Mustafa Karaca1, Murat Koçer, Mustafa Yıldız

\section{BASIC \& TRANSLATIONAL}

917 Determination of the changes on the small intestine of pregnant mice by histological, enzyme histochemical, and immunohistochemical methods

Erhan Şensoy, Yasemin Öznurlu

\section{Letters to the Editor}

925 Rare cause of severe hematemesis due to IgG4related gastric ulcer

Yu-Qin He, Xin Fu, Dong-Feng Chen

928 Necrotizing pancreatitis after removal of prophylactically placed pancreatic stent Sridhar Sundaram

930 Giant hepatic hemangioma: An unusual cause of gastric compression

Egemen Özdemir, Sami Akbulut, Koray Kutlutürk, Sezai Yılmaz

932 Segmental cytomegalovirus colitis mimicking sigmoid tumor in an immunocompetent patient

Carlos Cerdán Santacruz, Patricia Sáez Carlin, Rocío Santos Rancaño, Luis Ortega Medina Javier Cerdán Miguel

935 Application of preoperative endoscopic ultrasonographyguided carbon nanoparticle tattooing combined with titanium clip labeling in esophagogastric junction adenocarcinoma

Lan Lin, Ming Wang, Jie Hong, Sheng Yang, Yu Wang

937 Neutrophil-to-lymphocyte ratio alone may not be a true indicator of the severity of acute pancreatitis

Alpaslan Tanoğlu, Tolga Düzenli

\section{Gastroenterology Elsewhere}

938 Acute liver failure in adults Ali Rıza Çalışkan, Murat Harputluoğlu

\section{Erratum}

